(3) By means of the large pelagic material to subject a number of important oceanic species or genera to a finer analysis, with reference to classification, than has previously been possible with the frequently somewhat scanty material available from the distant waters.

The Expedition was successful in every way, and the results of the investigations now being published show its extreme value. It is to be regretted deeply that Schmidt did not live to see more of the fruits of his carefully planned work. The reports now being published are to appear in parts. No. 2 (Deep-Sea Angler Fishes (Ceratioidea)), by C. Tate Regan and Ethelwyn Trewavas, was published in 1932. Dr. Nielsen, who took part in the Expedition, now contributes an important monograph (No. 4) on the Ceratia in the southern Pacific Ocean. The genus is taken as representative of the phytoplankton and the whole work touches on many vital problems.

The Ceratium material is from two Danish Expeditions of the steamer Dana. In January 1922 in the Gulf of Panama and in September 1928-March 1929 on the present Expedition, through the Pacific Ocean from Panama to New Zealand-Australia, 68 stations were sampled, and in all the oceanic stations the Nansen closing net was used. Whilst on the first Expedition samples were taken at other depths, in 1928-29 the catches were almost wholly made at the depths 200-100 metres, 100-50 metres, 50-0 metres. The surface net was only used at shallow coastal stations where a vertical separation of species of Ceratium would be unimportant. Sixty species were recognised besides several sub-species and variations.

The larger part of these Ceratium species are oceanic, but a few are typically inhabitants of coastal waters, that is, neritic. The author's main conclusions are that temperature, currents and oceanicneritic waters are the chief factors influencing the horizontal distribution of the Ceratia, the variation in the species depending on the first and the last. $\mathrm{He}$ finds that a rising temperature tends to lessen the size of the cell, and, in some species, there is a lengthening of the horns at the same time. Under a neritic influence the cells are usually large and there is almost always a lengthening of the horns. The case of Ceratium fusus is striking, for in neritic waters it is nearly double the size of that in purely oceanic conditions. The cause of this large size is evidently not the better nourishment of the cell, since the Ceratium population in the eutrophic east equatorial stream where the neritic influence is much felt are no greater than in the oligotrophic oceanic stations with the same surface temperature. The author is of the opinion that the dearth of Ceratium species in purely neritic waters compared with the large numbers in the oceanic stations is to be attributed to the accumulation of the waste products from the breaking down of the many organisms in neritic regions where the water is only renewed very slowly, these substances being usually poisonous to the sensitive oceanic species.

There is a striking agreement of the Ceratium populations in the Pacific and Atlantic Oceans, few species being peculiar to one or the other.

It is shown that the genus has a very characteristic depth distribution. About a third of those found in the Pacific are so-called 'shadow' species. In the plankton-poor water these were found chiefly in the samples below 50 metres, whilst most of those where the plankton was rich were chiefly above this depth. The 'shadow' species are all oceanic. They require only a moderate light intensity, but in those waters where there is abundance of plankton this moderate light intensity is nearer the surface. All Ceratium species which have a very broad flattened body or in some other way have the assimilation surface enlarged are 'shadow' species. In those regions where they live, the nutrient salts are always considerable.

\title{
Genetics at Cold Spring Harbor, N.Y.
}

$\mathrm{T}$ HE latest annual report of Dr. C. B. Davenport for the Department of Genetics at Cold Spring Harbor is contained in Year Book No. 33 of the Carnegie Institution of Washington for 1934. It covers the usual wide range of investigations bearing on genetics in plants, animals and man. Only a few of these researches can be cited here. Demerec has surveyed the X-chromosome of Drosophila for minute deficiencies or cell-lethal mutations produced by $\mathrm{X}$-rays. In 12 out of 13 cases the deficiency of a single locus caused cell death, which supports the view that nearly all the genes take a vital part in the functioning of every cell. In $D$. virilis, a gene producing intersexes has been found.

Blakeslee and Bergner find that, in Datura discolor, five of the twelve pairs of chromosomes have exchanged segments in comparison with D. stramonium, and these species when crossed give a ring of 10 chromosomes in the hybrid. Older seeds are shown by Cartledge to have a higher mutation rate than young seeds, and it was found that bad pollen could be used as an index of the mutation rate in aged seeds, which produced mutations at thirty times the rate of the controls.
Problems of leukæmia and immunisation in mice are investigated, and an account is given of $\mathrm{Dr}$. Riddle's work on hormones, especially in pigeons. The antepituitary secretion has been most studied, both in pigeons and in cattle, some of the results receiving clinical application. It is shown that the gonad-stimulating hormone in rabbits also causes ovulation, but conclusive evidence is obtained that a separate pituitary principle stimulates the thyroid, also affecting the basal metabolism. The shaker mouse is found to show a defect in the area striata of the brain, and a circling mouse mutation is probably due to two recessive genes with variable expression. In the parasitic wasp, Habrobracon juglandis, Whiting has obtained sixty mutations. Some are sex-linked and form the basis for a theory of sex inheritance in this species with haploid males.

In human genetics there have been studies of growth in children, of the errors of physical anthropometry on the living subject, racial growth differences of Indians, Negroes and Dutch, and researches by Laughlin on immigration policy. 